\title{
Perception of technology as an assessment tool. A comparative analysis from the learner's perspective
}

\author{
M.Carmen Sarceda-Gorgoso \\ carmen.sarceda@usc.es \\ University of Santiago de Compostela, Spain

\section{Mari-Carmen Caldeiro-Pedreira} \\ mcarmen.caldeiro@usc.es \\ University of Santiago de Compostela, Spain
}

\section{Sandra Guevara-Betancourt}

smguevara@utn.edu.ec

Técnica del Norte University, Ecuador

\begin{abstract}
The current state of technology is unquestionably changing our lives and consequently, causing some effects in the educational field; specifically on higher education. Therefore, the objective of this work is to know the perception of higher education Ibero-American students with regard to technology as a learning assessment tool. The sample group is made up by 122 people studying at the Education School in Técnica del Norte University (Ecuador) and at the Teacher Training School in the University of Santiago de Compostela (Spain) who, throughout their educational trajectory, have been assessed at some point through technology. It is a quantitative study that applies the questionnaire as an instrument for data collection. Data analysis shows different perceptions, both in terms of contexts and experience itself, which allows us to identify those elements and factors influencing on the added value to technology as a resource for evaluation.
\end{abstract}

\section{Keywords}

ICT; higher education; user perceptions; assessment 


\section{Introduction}

Over the course of the last years, the social ecosystem has experienced remarkable changes, modifications mainly in the cultural, economic, and technological field. Society has been invaded by technology and content digitization; we are witnessing an almost indiscriminate and sometimes uncontrolled use of information and digital content being part of our lives (Renés, Caldeiro and Gozálvez, 2018). In general, it can be stated that "the technological and informational revolution reaches all areas and almost all the corners of our life" Aguaded (2018, p.7). Especially in countries such as Spain where Internet and computer access by 10 -year-old children is around $90 \%$. According to the National Institute of Statistics (NIS) website more than $90 \%$ of $10-15$-yearold children use the computer, Internet and mobile phone. This is an increasing percentage during recent years whose analysis by gender indicates that girls are more likely to use cellphones than boys. In addition to these figures, it is striking that the use of new technologies at home, by age groups, indicates that among the 16-24 years old the Internet is used almost universally; although, this use is inversely proportional to the rise in age.

Within this context, technology acquires a remarkable relevance; its use and access both to the Network, understood as a form of interconnection through nodes that is a way of projecting "from me towards you, and from us towards you all" (Ure, 2017, p.192). As well as access to the Internet is increasingly simple and is virtually done from anywhere on the planet. In this regard, it may be argued that, today, the digital divide is understood as the possibility for technological access, and it is not focusing on the concern but the knowledge gap, i.e., the cognitive differences that hinder the development of critical competence (Caldeiro and Aguaded, 2015) and social interaction.

Thus, education gets a decisive role at existing throughout life (Quendler and Lamb, 2016). Taking into account the fleeting nature of technology development and given that this becomes a "catalyst for change" (Camacho, 2017, p. 7), UNESCO (2015) made an appeal on this, pointing out the need of taking advantage of ICT if, by the year 2030, you want to achieve quality, inclusive, and equitable education along with lifelong learning. Then, agreeing with the work by (Lluna and Pedreira, 2017), titled the digital natives do not exist and for this reason, it is key to educate society in general for the digital world.

Education cannot ignore the technology that is constantly acquiring a decisive and fundamental value. In this respect, the institutions of higher education, aware of current transformations, are not unconnected to these changes. That is why, they channel their efforts towards promoting a new educational culture, starting from the qualification of their teachers, followed by the achievement and use of resources to allow the ICT insertion in education.

With this criteria most countries, in an international context, carry out initiatives to this end. Thus, for example, Higher Ecuadorian Education has to make the self-elaborated teaching materials visible in its websites, corresponding to the subjects, courses or their equivalents for undergraduate and postgraduate programs (Mejía-Madrid, Toala-Sánchez \& Valverde-Alulema, 2017); this, with the aim of promoting the ICT integration into their daily practice. The European Higher Education Area arises in response to the challenges posed by social and technological changes coming from the global knowledge society where we are immersed. To this end, the promotion of students' skills and competences is emphasized that practically means an adaptation of "the contents of university studies to social demands, improving their quality and competitiveness through greater transparency and student-based learning" (Sarceda-Gorgoso Rodicio-García, 2018, p.148). This would allow them to confront successfully the real challenges in an increasingly globalized society. 
In this way, the ICT implementation has been accelerated in recent years, becoming one of the main factors of change (Escobedo and Arteaga, 2015), stating that "the new technologies are presented as supporting tools in the implementation of educational methodologies, contributing to innovation of teaching practices when opening the door for a world full of possibilities that without ICT; it would not be possible" (Vázquez-Cupeiro and López-Pendedo, 2014, p.257). As well, this increases the active involvement of students in their learning process (Escobedo and Arteaga, 2015), evidencing that if there is a change "on the learning process and a diversification of knowledge typology, the evaluation might also gather evidence on the progression of different knowledge, and provide students information about this process" (Cano and Cabrera, 2013, p.48). This leads to carefully review the evaluation process and the roles developed by the different agents involved. As noted, although the professor does not cease to be the evaluator "is no longer the only element of that control because he is now who shares this task with students, those who get a very important role at becoming self and peers evaluators" (Jiménez, Llopis, Calaforra, Almagro, Alvarado and Puente 2016, p.67).

There is important reference to two new concepts linked to the assessment: self-evaluation and coevaluation. The participation of students in their assessment processes, as stated by Gijbels (2011), boosts the development of skills through reflection and collaboration, providing them with a greater active role, while at the same time, improving learning outcomes. This approach would correspond to one of the three types of evaluation in virtual contexts identified by Barberà (2016): The Collaborative Assessment. The Shared Assessment is added to these two dimensions which "represents the process of dialogue between professor with his students about the learning assessment; being relevant how communication channels are organized and implemented" (Romero-Martin, Castejón-Oliva López-Pastor and Fraile-Aranda, 2017, p. 74).

In addition, formative assessment gains importance when it enables the learning outcomes followup (Moreno and Rochera, 2016), fostering, at the same time, their self-regulating nature (RaposoRivas and Gallego-Arrufat, 2016). From this perspective, the feedback offered during the processes acquires a fundamental role because if we involve students in their evaluation process, they are more likely to move toward the learning pursued, at having the possibility to modify and reorient their work (Jiménez et al., 2016).

Thus, the ICT integration into teaching-learning contexts is the object of special attention, which is reflected both in the scientific events as in the high number of specialized journals on this topic. With regard to the assessment with ICT, the focus of our attention, it is possible to find a wide variety of works that deepen in their different dimensions.

In response to innovation, Escobedo and Arteaga (2015) focus on identifying, describing and analyzing the types, ways of access, use, and the perception students and professors have of ICT in the teaching-learning process. Rodríguez, Ibarra and Cubero (2018) expand on the perception university students have about their level of competence, in ten selected skills in relation to the processes of e-learning-oriented assessment. While Jimenez et al. (2016) through the insertion of ICT tools that allow students a continuous assessment of their own learning, carry out a project aimed at improving the quality of teaching, as well as to know the students' motivation and satisfaction. Romero-Martin et al. (2017) address the perception of teachers, students and graduates with regard to formative and shared assessment systems, and the acquisition of teaching competences in relation to communication and ICT use in initial training at a university level. Finally, Vázquez-Cupeiro and López-Pendedo (2014), describe two case studies in educational centers committed to educational innovation. 
At associating this approach with an interdisciplinary nature, an opinion becomes relevant from Hernández, Muñoz and González (2018), who delve into the analysis of the assessment of future teachers arising from the system of e-evaluation developed in an experience involving five subjects. Thus, along the same lines Cano and Cabrera (2013) with an experience in interdisciplinary nature involving 7 subjects of 6 universities in the Catalan territory.

Similarly, there are common studies that focus on the instruments used in the evaluation with ICT. Works on blogs (Cano and Cabrera, 2013), e-rubrics (Raposo-Rivas Gallego-Arrufat, 2016), questionnaires (Doménech and Fortea, 2015) or e-portfolios (Ausín, Abella and Delgado, 2017), provide very interesting conclusions about opportunity in the teaching-learning processes based on ICT. Less common are those studies, such as Moreno and Rochera (2016), where they address the major uses of Information and Communication Technologies (ICT) to assess and deliver formative feedback along the temporal dimension.

On the basis of the aforementioned, this study started with the aim of delving into knowledge of the ICT role in different contexts of Higher Education. This work follows the same lines of the already referenced, and it is approached from a perceptual dimension; as it is customary in recent years in educational research and, more specifically, in our object of study (Hernández et al., 2018, Raposo-Rivas Gallego-Arrufat, 2016, and Romero-Martin et al., 2017, Rodríguez et al., 2018, among others).

It should be noted that according to the four lines of research identified by Escobedo and Arteaga (2015) on ICT in the university education system (Studies on quantitative indicators to measure the level of introduction and use of ICT, studies on the effects of ICT on academic performance and learning outcomes, studies on the perspectives and opinions, assessment and evaluation by educational agents concerning to the use and integration of ICT; and studies on the practices of ICT use). This work would be placed in the third and fourth lines, since, on the one hand it aims to deepen the perceptions and views on the part of the educational agents, and on the other hand it takes the ICT application as framework for analysis.

Along with this, it should be noted that the object of study is located in two distinct scenarios of Higher Education: Ecuador and Spain. The choice of these two countries with disparate contexts responds to the intention of approaching perceptions related to different social and economic circumstances, which are reflected in differentiated procedures of technology integration in teaching-learning processes. Hence, the comparative dimension makes the observation of implementation level and nature of technologies possible, on the basis of each scenario approach; regarding to the evaluation with ICT.

\section{Method}

This is a quantitative and descriptive study that uses the questionnaire as an instrument for data collection.

\section{Objectives}

The research objectives are:

1) To know students' perceptions about their experience in evaluation with ICT, at a global level and in each study context

2) To identify the variables influencing those perceptions 


\section{Participants}

The sample selected with intentional and indirect nature (Table 1), is made up by 122 students from the Education School at Técnica del Norte University (Ecuador) and the Teacher Training School at University of Santiago de Compostela (Spain), who along their educational path have been evaluated at some point through technology.

Characterizing their profile and considering their gender, female representation (54.9\%) is slightly higher than male $(45.1 \%)$, and the age range is mostly between 20 and 25 years old $(62.3 \%)$. The target population surveyed considers having an average knowledge of technology (45.9\%) or even high $(39.3 \%)$ and has been involved in assessment processes with ICT, for the most part, two or three times $(53.3 \%)$, describing the experience as regular $(40.2 \%)$ or good $(38.5 \%)$.

\begin{tabular}{|c|c|c|c|}
\hline & & $\mathbf{N}$ & $\%$ \\
\hline \multirow{2}{*}{ University } & Técnica del Norte & 61 & 50 \\
\hline & Santiago De Compostela & 61 & 50 \\
\hline \multirow{2}{*}{ Gender } & Male & 55 & 45,1 \\
\hline & Female & 67 & 54,9 \\
\hline \multirow{4}{*}{ Age } & Less than 20 years old & 39 & 32,0 \\
\hline & $\begin{array}{l}\text { Between } 20 \text { and } 25 \text { years } \\
\text { old }\end{array}$ & 76 & 62,3 \\
\hline & $\begin{array}{l}\text { Between } 26 \text { and } 30 \text { years } \\
\text { old }\end{array}$ & 6 & 4,9 \\
\hline & More than 30 years old & 1 & 8 \\
\hline \multirow{5}{*}{$\begin{array}{l}\text { Knowledge of } \\
\text { technology }\end{array}$} & Very low & 0 & 0 \\
\hline & Low & 3 & 2,5 \\
\hline & Medium & 56 & 45,9 \\
\hline & High & 48 & 39,3 \\
\hline & Very high & 15 & 12,3 \\
\hline \multirow{3}{*}{$\begin{array}{l}\text { No. of times been } \\
\text { evaluated with ICT }\end{array}$} & Once & 21 & 17,2 \\
\hline & Twice to three times & 65 & 53,3 \\
\hline & More than three times & 36 & 29,5 \\
\hline \multirow{5}{*}{$\begin{array}{l}\text { Experience in the } \\
\text { evaluation with ICT }\end{array}$} & Very bad & 0 & 0 \\
\hline & Bad & 12 & 9,8 \\
\hline & Regular & 49 & 40,2 \\
\hline & Good & 47 & 38,5 \\
\hline & Very good. & 14 & 11,5 \\
\hline
\end{tabular}

Table 1. Characteristics of the sample

Source: The authors

\section{Procedure and Instrument}

The instrument used for the data collection was the questionnaire, usual in this type of studies (Cano and Cabrera, 2013; Hernández et al., 2018; Pegalajar, 2017; Raposo-Rivas and GallegoArrufat, 2016; Romero-Martín et al., 2017; Rodríguez et al., 2018). In this case, it was the "Evaluation Questionnaire with ICT (CUDE \& ICT)", developed ad hoc and made up by 3 dimensions, answered in a Likert-type scale in measure and degree of 5 points. One of these dimensions, in particular, the assessment with ICT, is the object of analysis in this work. 
Once the instrument was designed, its content validation was performed in two phases: in the first instance, by a judgment criteria of 10 experts with extensive expertise in the field of Didactics and ICT; handling criteria of relevance and understanding. These experts have a coefficient of competition (Oñate, Ramos and Díaz., 1990) in all cases, higher than 0.8. When suggestions were applied, in a second time, a pilot test was conducted in paper format to 30 university students (15 in Ecuador and 15 in Spain), in order to determine understanding and clarity of the statements, without having to make changes at that point.

Finally, an electronic version of the instrument was created on Google Forms tool. Then, faculty from Education School at Técnica del Norte University (Ecuador), and Teacher Training School at the University of Santiago de Compostela (Spain) were contacted and informed about this study. After the mutual collaboration was agreed, the questionnaire was sent to students by means of the virtual platform in each university. There were two reminders with the aim of obtaining a wide sample. Prior to their completion, each student received the necessary instructions, ensuring at all times the confidentiality and anonymity of the data collected.

Once the database with the information obtained was elaborated, it was possible to determine the reliability and construct validity of the instrument. For the whole questionnaire the statistical Cronbach's alpha is $a=.941$, and for the relative items to the assessment with ICT, object of this work, the statistical Cronbach's alpha is $a=.950$, values that reveal an excellent internal consistency.

\section{Data Analysis}

Descriptive and inferential statistics were combined: statistical data reliability (Cronbach's a), Pearson's chi-square coefficient, and Kruskal-Wallis test. The tests are non-parametric because the measurement scale is an ordinal type. Treatment and analysis of data were carried out using SPSS 25.0; a statistics program for Windows.

\section{Results}

In response to the average scores (Table 2), almost all items considered reach values higher than 3 , appearing the greater value in relation to the assessment with ICT has improved the evaluation process $(\mathrm{M}=3,57 ; \mathrm{SD}=, 987)$, offered information which has made it possible to improve the level of competence as a future professional $(\mathrm{M}=3,54 ; \mathrm{SD}=1,049)$, and has been a guide and help to learn $(M=3,51 ; S D=1,100)$. At the opposite pole, the lowest average score refers to the opportunity of the evaluation with ICT to allow interaction with other partners $(M=2,98$; $S D=$ $1,076)$.

Taking into account the contexts (Ecuador and Spain), the analyzes show that, in 11 of the 14 items considered, the average reached are slightly higher in the Spanish Framework than in the Ecuadorian, presenting this last one a higher average only with regard to the perception about the improvement that involves the use of ICT in the assessment process (item 4). Two other aspects (item 7 and item 8) show average scores identical in both scenarios (3,36 and 3,26, respectively).

\begin{tabular}{lcccccc}
\multirow{2}{*}{ The evaluation with ICT.... } & \multicolumn{2}{c}{ Global } & \multicolumn{2}{c}{ Spain } & \multicolumn{2}{c}{ Ecuador } \\
\cline { 2 - 7 } & $\mathrm{M}$ & $\mathrm{SD}$ & $\mathrm{M}$ & $\mathrm{SD}$ & $\mathrm{M}$ & $\mathrm{SD}$ \\
\hline 1. It has allowed me to interact with other & 2,98 & 1,076 & 3,15 & 1,030 & 2,82 & 1,103 \\
\hline
\end{tabular}




\begin{tabular}{|c|c|c|c|c|c|c|}
\hline classmates & & & & & & \\
\hline 2. It has enabled a collaborative work & 3,36 & 1,053 & 3,52 & ,924 & 3,20 & 1,152 \\
\hline $\begin{array}{l}\text { 3. It has been carried out through co- } \\
\text { assessment among peers }\end{array}$ & 3,03 & 1,120 & 3,15 & 1,078 & 2,92 & 1,159 \\
\hline 4. It has improved the evaluation process & 3,57 & 987 & 3,49 & ,942 & 3,64 & 1,033 \\
\hline $\begin{array}{l}\text { 5. I have been stimulated at a motivational } \\
\text { level }\end{array}$ & 3,25 & 1,047 & 3,28 & 1,067 & 3,21 & 1,035 \\
\hline $\begin{array}{l}\text { 6. It has provided high quality information } \\
\text { that helps me for self-assessment }\end{array}$ & 3,45 & 1,037 & 3,52 & ,993 & 3,38 & 1,083 \\
\hline $\begin{array}{l}\text { 7. It has fostered my self-reflection on the } \\
\text { learning outcomes }\end{array}$ & 3,36 & 1,005 & 3,36 & 1,001 & 3,36 & 1,017 \\
\hline $\begin{array}{l}\text { 8. It has promoted the participation of } \\
\text { students in the assessment process }\end{array}$ & 3,26 & 1,074 & 3,26 & 1,094 & 3,26 & 1,063 \\
\hline 9. It has given me feedback & 3,30 & 1,120 & 3,44 & ,975 & 3,16 & 1,241 \\
\hline $\begin{array}{l}\text { 10. It has offered me information which has } \\
\text { allowed me to correct mistakes }\end{array}$ & 3,33 & 1,071 & 3,43 & 991 & 3,23 & 1,146 \\
\hline $\begin{array}{l}\text { 11. It has offered information that has } \\
\text { allowed me to improve my competence } \\
\text { level as a future professional }\end{array}$ & 3,54 & 1,049 & 3,65 & ,899 & 3,43 & 1,176 \\
\hline $\begin{array}{l}\text { 12. It has been a useful guide and help to } \\
\text { learn }\end{array}$ & 3,51 & 1,100 & 3,48 & 1,058 & 3,54 & 1,149 \\
\hline 13. It has favored my self-esteem & 3,00 & 1,192 & 3,03 & 1,154 & 2,97 & 1,238 \\
\hline 14. It has favored my positive motivation & 3,18 & 1,185 & 3,23 & 1,086 & 3,13 & 1,284 \\
\hline
\end{tabular}

${ }^{*}$ Kruskal Wallis test

Table 2. Average scores and standard deviation of the sample

Source: The authors

The research aims to know if the differences are significant. For this effect the chi-square test was applied, checking that the contexts do not influence the perception that participants express about their evaluation with ICT ( $p>0,05$ in all cases).

On the other hand, the purpose is to identify elements that may influence the perception of the participants in relation to these items as well, taking as fixed factors or independent variables "gender", "age", "number of times being evaluated with ICT", the "knowledge of technology," and "experience in assessment".

On the basis of the "gender", once the chi-square test was applied, despite the fact that, as noted above, the use of technologies such as cellphone by girls is occurring earlier, this study finds that there are no significant differences on dependent variables $(p>0,05)$. In addition, the KruskalWallis $\mathrm{H}$ test does not show significant differences in function of the "number of times being evaluated with ICT," or the "knowledge of technology".

On the other hand, there are influences of the variable "age" in relation to the item 2: evaluation with ICT has enabled collaborative work $(p=, 008)$, and if one considers the "experience in the evaluation with ICT" (Table 3 ), the results show that differences acquire significance in all items considered at a level $p=.000$ and $p=.001$, which gives an account of the strong associations between variables.

F f.d Sig. 
1. The ICT evaluation has allowed me to interact with other classmates

\begin{tabular}{|c|c|c|c|}
\hline 2. It has enabled a collaborative work & 18,133 & 3 & .000 \\
\hline 3. It has been carried out through co-assessment among peers & 18,928 & 3 & .000 \\
\hline 4. It has improved the evaluation process & 16,823 & 3 & .001 \\
\hline 5. I have been stimulated at a motivational level & 28,286 & 3 & .000 \\
\hline 6. It has provided high quality information that helps me for self-assessment & 23,206 & 3 & .000 \\
\hline 7. It has fostered my self-reflection on the learning outcomes & 22,577 & 3 & .000 \\
\hline 8. It has promoted the participation of students in the assessment process & 19,139 & 3 & .000 \\
\hline 9. It has given me feedback & 20,245 & 3 & .000 \\
\hline 10. It has offered me information which has allowed me to correct mistakes & 18,150 & 3 & .000 \\
\hline $\begin{array}{l}\text { 11. It has offered me information that has allowed me to improve my } \\
\text { competence level as a future professional }\end{array}$ & 19,770 & 3 & .000 \\
\hline 12. It has been a useful guide and help to learn & 23,472 & 3 & .000 \\
\hline 13. It has favored my self-esteem & 25,517 & 3 & .000 \\
\hline 14. It has favored my positive motivation & 25,830 & 3 & .000 \\
\hline
\end{tabular}

* Kruskal Wallis test

Table 3. Significant differences in perception of the experience in evaluation with ICT

Source: The authors

In addition, this study searches the possible existing differences in each of the response groups. To this end, the response scale of the independent variable was re-categorized in three groups: very bad/poor, regular, good/very good. The Kurskal-Wallis test was applied again, which allows us to verify that it is the student body that considers the evaluation experience with ICT as good/very good, it values more positively the items analyzed, as derived from the values of the average range (Table 4), particularly high in relation to item 14 (has favored the positive motivation), where $\mathrm{R}=74,66$.

VB / P: very bad/poor; R: regular; G / VG: good/very good.

\begin{tabular}{lcc} 
Exper. & N & $\begin{array}{c}\text { Average } \\
\text { Range }\end{array}$ \\
VB/P & 12 & 29,17 \\
\hline R & 49 & 56,47 \\
\hline G / VG & 61 & 71,90 \\
\hline Total & 122 & \\
\hline VB/P & 12 & 41,58 \\
\hline R & 49 & 52,33 \\
\hline G / VG & 61 & 72,79 \\
\hline Total & 122 & \\
\hline VB/P & 12 & 28,17 \\
\hline R & 49 & 56,13 \\
\hline G / VG & 61 & 72,37 \\
\hline Total & 122 & \\
\hline VB/P & 12 & 36,38 \\
\hline R & 49 & 53,49 \\
\hline G / VG & 61 & 72,88 \\
\hline Total & 122 & \\
\hline VB/P & 12 & 19,08 \\
\hline R & 49 & 56,67 \\
\hline G / VG & 61 & 73,72 \\
\hline & \multicolumn{2}{l}{} \\
\hline
\end{tabular}




\begin{tabular}{|c|c|c|c|}
\hline & Total & 122 & \\
\hline \multirow{4}{*}{$\begin{array}{l}\text { 6. It has provided high quality information that helps me for self- } \\
\text { assessment }\end{array}$} & $\mathrm{VB} / \mathrm{P}$ & 12 & 24,58 \\
\hline & $\mathrm{R}$ & 49 & 56,22 \\
\hline & G / VG & 61 & 73,00 \\
\hline & Total & 122 & \\
\hline \multirow{4}{*}{ 7. It has fostered my self-reflection on the learning outcomes } & VB/P & 12 & 26,04 \\
\hline & $\mathrm{R}$ & 49 & 55,98 \\
\hline & G / VG & 61 & 72,91 \\
\hline & Total & 122 & \\
\hline \multirow{4}{*}{$\begin{array}{l}\text { 8. It has promoted the participation of students in the assessment } \\
\text { process }\end{array}$} & VB/P & 12 & 28,50 \\
\hline & $\mathrm{R}$ & 49 & 56,31 \\
\hline & $\mathrm{G} / \mathrm{VG}$ & 61 & 72,16 \\
\hline & Total & 122 & \\
\hline \multirow{4}{*}{ 9. It has given me feedback } & VB/P & 12 & 30,96 \\
\hline & $\mathrm{R}$ & 49 & 54,23 \\
\hline & $\mathrm{G} / \mathrm{VG}$ & 61 & 73,34 \\
\hline & Total & 122 & \\
\hline \multirow{4}{*}{$\begin{array}{l}\text { 10. It has offered me information which has allowed me to correct } \\
\text { mistakes }\end{array}$} & VB/P & 12 & 29,96 \\
\hline & $\mathrm{R}$ & 49 & 55,86 \\
\hline & $\mathrm{G} / \mathrm{VG}$ & 61 & 72,24 \\
\hline & Total & 122 & \\
\hline \multirow{4}{*}{$\begin{array}{l}\text { 11. It has offered me information that has allowed me to improve my } \\
\text { competence level as a future professional }\end{array}$} & VB/P & 12 & 38,17 \\
\hline & $\mathrm{R}$ & 49 & 51,02 \\
\hline & $\mathrm{G} / \mathrm{VG}$ & 61 & 74,51 \\
\hline & Total & 122 & \\
\hline \multirow{4}{*}{ 12. It has been a useful guide and help to learn } & VB/P & 12 & 27,38 \\
\hline & $\mathrm{R}$ & 49 & 53,86 \\
\hline & G / VG & 61 & 74,35 \\
\hline & Total & 122 & \\
\hline \multirow{4}{*}{ 13. It has favored my self-esteem } & VB/P & 12 & 19,75 \\
\hline & $\mathrm{R}$ & 49 & 57,52 \\
\hline & G / VG & 61 & 72,91 \\
\hline & Total & 122 & \\
\hline \multirow{4}{*}{ 14. It has favored my positive motivation } & VB/P & 12 & 23,79 \\
\hline & $\mathrm{R}$ & 49 & 54,36 \\
\hline & G / VG & 61 & 74,66 \\
\hline & Total & 122 & \\
\hline
\end{tabular}

\footnotetext{
${ }^{*}$ Kruskal Wallis Test

VB / P: very bad/poor; R: regular; G / VG: good/very good.

Table 4. Kruskal Wallis Test (grouping variable: assessment of experience)

Source: The authors
}

\section{Conclusions and Discussion}

In response to the first objective "To know students' perceptions about their experience in evaluation with ICT at a global level and in each study context", there was a descriptive analysis in order to identify what were the highest rated possibilities and advantages of e-evaluation. 
The results obtained (Table 2 ) show that all the possibilities offered by the assessment with ICT reach higher values than the average, being the items relative to the improvement of the evaluation process, information that provides for the improvement of the professional level of competence, and to the guide and help offered to learn, which are the most positively rated. These results show the potential of the assessment with ICT, in the same line Ion, Silva and García (2013) call feedforward or prospective feedback, and that has to do with the capacity of the eassessment to enhance learning in the present and throughout life (Quember and Lamb, 2016) in both dimensions; academic and labor.

High values are reached by the variables that have to do with the e-evaluation as a tool that enhances reflection. Keep in mind that this is a singular fact that only facilitates some methodological options for evaluation (Barberà, 2016), which requires, as pointed out by Zapata, Ospina, Sepúlveda and López (2013), the search for alternatives that modify conventional methods used in the evaluation practices. Thus, the analysis of the instruments used in the e-assessment will provide with more information on this dimension, not being unreasonable to hypothesize about the influence of e-rubrics (Raposo-Rivas and Gallego-Arrufat, 2016), e-portfolios (Ausin et al., 2017; Cano and Cabrera, 2013), e-questionnaires (Doménech and Fortea, 2015) or Blogs (Cano and Cabrera, 2013) as instruments of evaluation with ICT that favor self-reflection.

Finally, it is noted that the self-assessment, co-assessment and shared assessment, are dimensions enhanced by the e-assessment. In response to the self-assessment, previous research (Hernández et al., 2018) highlight the importance that students give to the professor's feedback for self-regulation of evaluation, becoming partakers and connoisseurs of the process (Jiménez et al., 2016), although it also recognizes that it is not a process free of difficulties (Li et al., 2016), among other reasons because it must meet several conditions.

Accordingly, Cano and Cabrera (2013) point out the following: "to be agile enough, indicate strengths and weaknesses, and suggest actions to overcome the mistake and try other forms of resolution" (p.48). In this work, the ratings on the feedback are in the same line with the results offered by Cano and Cabrera (2013), with high scores which demonstrate the ability of the evaluation with ICT to provide positive feedback to the progress in learning.

With regard to co-assessment, the average scores are somewhat higher than those presented in Romero-Martet al. (2017), which invites the optimism. However, we defend the need to continue moving forward on the subject, given the importance of this procedure for an evaluation that pretends to be formative and oriented towards learning. Finally, and in response to the shared assessment, the fundamental role of ICT in this area is noted, as facilitators of the "generation of links and networks - social capital - among their peers and the professor who is in charge of the subject" (Escobedo and Arteaga, 2015, p. 119), to achieve the items connected to this dimension; values higher to 3 points in all cases.

On the other hand, it was interesting "To identify the variables that influence these perceptions". This work selected as fixed factors, gender, number of times being evaluated with ICT, knowledge of technology, age, and experience in evaluation; regarding to the first three, although there are differences, after the corresponding statistical analysis, they are not shown as significant. Considering the gender, the results differ from what was happening in previous studies. In Rodríguez, et. al (2018), there were divergences linked to gender in relation to the perception of university students on their competence level; as far as the processes of e-evaluation, and that is not presented in this work. The number of times they have participated in the evaluation with ICT does not show any influence on the valuation of items considered. 
With regard to the perception of the ICT knowledge, participants in this study consider themselves having a high or medium level (Table 1), disagreeing with other precedents (Gutiérrez-Martín, Palacios and Torrego, 2010; Romero-Martín et al., 2017) in which this knowledge is not verified. Despite this perception about technological competence, the results obtained show that there is no relation with the valuation of possibilities in assessment with ICT.

The positive correlation between the perception of the experience lived in the evaluation with ICT and the possibilities granted; it is the most important contribution of this work (Table 3), being the students with better perception who present the higher average ranges (Table 4). In previous studies, the importance of satisfaction with e-assessment for competence development and motivation toward learning has been already highlighted (Raposo-Rivas and Gallego-Arrufat, 2016; Rodríguez et al., 2018; Romero-Martin et al., 2017). This work notes that capabilities such as to work and interact with peers, to obtain feedback, to strength self-reflection on learning, selfesteem and motivation, or to self-regulate learning, are enhanced when the assessment with ICT has been satisfactory.

The results presented in this study are of interest to the teaching field that integrates technology and, more specifically, the e-assessment in its teaching and learning proposals. Collecting the ratings of the learners in evaluating experiences with ICT in virtual environments is an important source of information, and the instrument used (CUDE \& ICT) meets the necessary methodological requirements; however, there is no doubt about the existing limitations that will be required to be overcome in further studies.

First of all, there is caution with the conclusions due to the number, relatively small of participants. Only later studies, with a larger sample both in terms of the number of students and contexts, will be able to confirm if they are maintained, nuanced or even refuted. Right now, this instrument is being applied in other countries from both Europe and Ibero-America, which will provide a greater generalization to the data obtained.

Also, it would be important a complementarity in methodology because this work is addressed solely from a quantitative approach. In future replications, it may be strengthened by introducing a methodological change complementing this study with other techniques for data collection, such as interviews or focus groups, in the same line as Hernández et al., (2018) who combine the application of the questionnaire with the realization of case studies; or opting for a pretest-posttest design in rating satisfaction with e-assessment, which may offer opportunities to determine possible changes in the perception of the student body.

On the other hand, this study would be enriched even more when approaching the perception of other agent involved didactically: the faculty, following the footsteps of previous works (Cano and Cabrera, 2013; Romero-Martín et al., 2017). In the literature review about this subject, the importance of teacher training in regard to the use of methodological and pedagogical ICT is highlighted. This, given that its integration in the classroom inevitably requires a change in the faculty role who must evolve from the transmission toward the mediation of knowledge construction (Escobedo and Arteaga, 2015; Romero-Martín al., 2017), which generates problematic issues. Some of them have to do with the possible gap between teachers and students in the use of ICT when teachers fail to take advantage of these tools at not knowing how to use them methodologically in the teaching-learning process, and if the curricula are not prepared in accordance with the current needs of training (Zapata et al., 2013). Thus, it may be of great interest to deepen in the teachers training aimed at the integration of ICT into the teachinglearning process; this due to the fact that their competences will be determinant for decision- 
making and achieve quality in the process (Romero-Martín et al., 2017), as well as for the educational perspective that supports the use of ICT in the evaluative processes (Moreno and Rochera, 2016). Even though it was already pointed out, the differences between the Ecuadorian and Spanish context are not that meaningful; however, they do exist. Thus, a larger sample group could provide a more detailed information in this regard. Authorship criteria were based on all the aspects above mentioned.

\section{Acknowledgments}

This work has been carried out in the framework of the Galician Group curriculum for training and labor insertion (GEFIL, GI-1867) and the Network of Immigration, Education and Society (RIES, GI-1790).

\section{References}

Aguaded, I. (2018). Medios emergentes en una nueva sociedad digital: la revolución educomunicativa. En García-Ruiz, R.; Pérez-Rodriguez, A. \& Torres, A. Educar para los nuevos medios. Claves para el desarrollo de la competencia mediática en el entorno digital (pp. 7-12). Ecuador: Abya-Yala.

Ausín, V., Abella, V \& Delgado, V. (2017). Implicación del alumnado en la evaluación a través de portfolio electrónico. Infancia, Educación y Aprendizaje (IEYA), 3(2), 77-81. Retrieved from: https://revistas.uv.cl/index.php/IEYA/article/view/703/678

Barberà, E. (2016). Aportaciones de la tecnología a la e-Evaluación. RED. Revista de Educación a Distancia, 50, 1-10. Retrieved from: http://www.redalyc.org/articulo.oa?id=54746291005

Caldeiro, MC. \& Aguaded-Gómez, J. (2015). «Estoy aprendiendo, no me molestes» la competencia mediática como forma de expresión crítica de nativos e inmigrantes digitales. Redes.com, 12. Retrieved from: http://goo.gl/2ORkf1

Camacho, M. (2017). Tablets en educación. Hacia un aprendizaje basado en las competencias. Recuperado de https://goo.gl/5tjQxh

Cano, E. \& Cabrera, N. (2013). La evaluación formativa de competencias a través de blogs. La experiencia de seis universidades catalanas. Digital Education Review, 23, 46-58. Retrieved from: http://revistes.ub.edu/index.php/der/article/view/11286

Doménech, F. \& Fortea, M.A. (2015). Validez factorial de un cuestionario para evaluar la percepción inicial de los estudiantes universitarios sobre la evaluación de los aprendizajes. Electronic Journal of Research in Educational Psychology, 13(3), 569-586. doi: 10.14204/ejrep.37.14113

Escobedo, C. \& Arteaga, E. (2015). Evaluación de los estudiantes y docentes sobre las Tecnologías de Información y Comunicación en los procesos de enseñanza - aprendizaje: una mirada desde la carrera de Sociología de la UC Temuco. Un estudio de caso. Digital Education Review, 28, 102-122 Retrieved from: http://revistes.ub.edu/index.php/der/article/view/11928

Gijbels, D. (2011). Assessment of vocational competence in higher education: reflections and prospects. Assessment and Evaluation in Higher Education, 36(4), 381-383

Gutiérrez-Martín, A., Palacios, A., \& Torrego, L. (2010). Formar al profesorado inicialmente en habilidades y competencias en TIC: perfiles de una experiencia colaborativa. Revista de Educación, 352, 149-178

Hernández, N., Muñoz, P. \& González, M. (2018). La e-evaluación en el trabajo colaborativo en entornos virtuales: Análisis de la percepción de los estudiantes. Edutec. Revista Electrónica de Tecnología Educativa, 65, 16-28. Retrieved from: doi:https://doi.org/10.21556/edutec.2018.65.997

INE (2018). La Encuesta TIC-H 2017. Disponible en https://goo.gl/Hxs1BT

Ion, G., Silva, P. \& García, E. (2013) El feedback y el feedforward en la evaluación de las competencias de estudiantes universitarios. Revista Profesorado, 17(2), 287-301. Retrieved from:: http://www.ugr.es/ recfpro/rev172COL4.pdf

Jiménez, V., Llopis, C., Calaforra, P.J., Almagro, P.J., Alvarado, J.M. \& Puente, A. (2016). Utilización de códigos QR para la evaluación continua en educación superior. CEF, 5, 65-85 
Li, H., Xiong, Y., Zang, X., Kornhaber, M.L., Lyu, Y., Chung, K.S., \& Suen, H.K. (2016). Peer Assessment in the Digital Age: a Meta-Analysis Comparing Peer and Teacher Ratings. Assessment \& Evaluation in Higher Education, 41(2), 245-264. doi: 10.1080/02602938.2014.999746

Lluna, S. \& Pedreira, J. (2017). Los nativos digitales no existen. Cómo educar a tus hijos para un mundo digital. Ediciones Deusto: Barcelona.

Mejía-Madrid, G., Toala-Sánchez, G. \& Valverde-Alulema, F. (2017). Modelo para evaluar el uso de la tecnología para el aprendizaje y la adquisición del conocimiento dentro del proceso de enseñanza aprendizaje. Revista Publicando, 4 (11), 228-247

Moreno, L.L \& Rochera, M. J. (2016). Usos de las TIC y su temporalidad en prácticas evaluativas del profesorado de educación secundaria. Digital Education Review, 30, 147-164. Retrieved from: http://revistes.ub.edu/index.php/der/article/view/15235/pdf

Oñate, N., Ramos, L. \& Díaz, A. (1990). Utilización del Método Delphi en la pronosticación: una experiencia inicial. La Habana: Instituto de Investigaciones Económicas de la Junta Central de Planificación.

Pegalajar, M.C (2017). El futuro docente ante el uso de las TIC para la educación inclusiva. Digital Education Review, 31, 131-148. Retrieved from: http://revistes.ub.edu/index.php/der/article/viewFile/16016/pdf

Quendler, E. \& Lamb, M. (2016). Learning as a lifelong process - meeting the challenges of the changing employability landscape: competences, skills and knowledge for sustainable development. International Journal of Continuing Engineering Education and Life Long Learning, 26(3), 273-293. Retrieved from: https://doi.org/10.1504/IJCEELL.2016.078447

Raposo-Rivas, M. \& Gallego-Arrufat, M.J. (2016). University Students' Perceptions of Electronic Rubric-Based Assessment. Digital Education Review, 30, 220-233. Retrieved from: http://revistes.ub.edu/index.php/der/article/view/15442

Renés, P., Caldeiro, MC \& Gozálvez, V. (2018). Educar para la ciudadanía digital, responsable y autónoma. Harvard Deusto, 15, 10-17

Romero-Martín, M.R., Castejón-Oliva, F.J., López-Pastor, V.M. \& Fraile-Aranda, A. (2017). Evaluación formativa, competencias comunicativas y TIC en la formación del profesorado. Comunicar, 52, 73-82. doi: https://doi.org/10.3916/C52-2017-07

Rodríguez, G., Ibarra, M. S. \& Cubero, J. (2018). Competencias básicas relacionadas con la evaluación. Un estudio sobre la percepción de los estudiantes universitarios. Educación XX1, 21 (1), 181-208. doi: 10.5944/educXX1.14457

Sarceda-Gorgoso, M.C. \& Rodicio-García, M.L (2018). Escenarios formativos y competencias profesionales en la formación inicial del profesorado. Revista Complutense de Educación, 29 (1), 147-164

UNESCO (2015). Declaración de Qingdao (2015). Aprovechar las oportunidades digitales, liderar la transformación de la educación. Retrieved from: https://goo.gl/Upg6Dm

Ure, M. (2017). De la alteridad a la hiperalteridad: la relación con el otro en la Sociedad Red. Sophia, colección de Filosofía de la Educación, 22(1), 193-212. Retrieved from: https://doi.org/10.17163/soph.n22.2017.08

Vázquez-Cupeiro, S. \& López-Pendedo, S. (2014). Escuela, TIC e innovación educativa. Digital Education Review, 30, 248-261. Retrieved from: revistes.ub.edu/index.php/der/article/download/15367/pdf

Zapata, L.; Ospina, J.; Sepúlveda JM. \& López-Murillo, E. (2013). Prototipo de evaluación con TIC: Un paso hacia el cambio curricular. Trilogía, 8, 93-108. Retrieved from: https://doi.org/10.22430/21457778.295 